\title{
Phosphate fertilization changes the characteristics of 'Maçã' banana starch
}

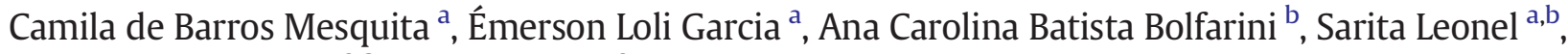 \\ Célia Maria L. Franco ${ }^{\mathrm{a}, \mathrm{c}}$, Magali Leonel ${ }^{\mathrm{a}, *}$ \\ a Center for Tropical Roots and Starches (CERAT), São Paulo State University (UNESP), Botucatu, São Paulo, Brazil \\ ${ }^{\mathrm{b}}$ Department of Horticulture, College of Agricultural Sciences (FCA), UNESP, Botucatu, São Paulo, Brazil \\ c Department of Food Engineering and Technology, Institute of Biosciences, Language, and Physical Sciences (IBILCE), UNESP, São José do Rio Preto, São Paulo, Brazil
}

\section{A R T I C L E I N F O}

\section{Article history:}

Received 19 October 2017

Received in revised form 5 February 2018

Accepted 11 February 2018

Available online 13 February 2018

\section{Keywords:}

Musa spp.

Phosphate fertilizer

Starch

\begin{abstract}
A B S T R A C T
The unripe banana has been studied as a potential source of starch for use in various applications. Considering the importance of phosphorus in the biosynthesis of the starch and also the interference of this mineral in starch properties, in this study it was evaluated the effect of rates of phosphate fertilizer applied in the cultivation of 'Maçã' banana on the characteristics of the starch. Starches extracted from fruits from different treatments were analyzed for morphological characteristics, X-ray diffraction pattern, relative crystallinity, granule size, amylose, resistant starch and phosphorus levels, as well as, for pasting and thermal properties. Results showed that the phosphate fertilization has interference on the characteristics of the banana starch led to increase of phosphorus content and size of the granules, reduction of crystallinity and resistant starch content, decrease of viscosity peak, breakdown, final viscosity, setback, transitions temperatures and enthalpy. These changes caused by phosphate fertilizer conditions can be increase the applications of the 'Maçã' banana starch.
\end{abstract}

(C) 2018 Published by Elsevier B.V.

\section{Introduction}

Exploited largely by small farmers, banana plantation plays an important socio-economic role in many countries, contributing not only to income but also to food security. Brazil is the world's largest producer of bananas with less production than only Ecuador and India [1]. Consumption per capita of the fruits in nature is large (7.68 kg/year); however, the industrialization is still small compared to the country's agricultural production [2].

More than 300 types of bananas are cultivated throughout the world. These are grouped according to the number of chromosome sets present and the proportion of genomes of M. acuminata (A) and M. balbisiana (B) [3]. In Brazil the most cultivated genotypes are those of the subgroup Prata (Prata, Pacovan, Prata Anã and Maçã) and the Cavendish group (Nanica, Nanicão and Grand Naine), since they attend important aspects related to agricultural production and palate.

The banana fruit when unripe has considerable starch content and due to the high market value of this carbohydrate, the interest of producers and industrialists on information regarding the use of this fruits as source of unconventional commercial starch has increased.

The starch due to its characteristics such as abundant availability, renewable energy source, high biodegradability and low toxicity,

\footnotetext{
* Corresponding author.

E-mail address: mleonel@cerat.unesp.br (M. Leonel).
}

combined with high purity and ample possibility of conversion to various substances by chemical and biochemical processes, shows immense potential of applications [4].

Considering banana as a potential source of commercial starches, studies are needed to optimize agricultural production for this purpose. In this line, research that integrates cultural practices with yield and starch properties, similar to the advances already achieved with other sources of starch are of considerable importance.

Phosphorus (P) is an essential nutrient for plants and has a role in the respiration, production and processes of transformation of energy by the plant, as well as in cell division. This nutrient is rapidly mobilized in plants and, when deficient, it translocates from the older tissues to the active meristematic regions. However, limitations on the availability of this mineral at the beginning of the vegetative cycle can result in lower development, of which the plant does not recover afterward, even increasing its supply to adequate levels [5].

Phosphorus deficiency in banana plant led to a low development, reduced root formation, yellowing and twisting of older leaves, petiole breakage and stunted bunches, irregular ripening, as well as unpalatable fruits [6].

In addition to the importance of phosphorus in plant development, this nutrient plays significant roles in the functional properties of starches. The increase of the phosphorus linked to the starch affects the colloidal capacity, characterized by increasing the swelling power and the solubilization of the granules, reducing the gelatinization 
temperature, as well as increasing the clarity of the paste and the viscosity of the gel. Besides these, starch pastes exhibit greater resistance to retrogradation. These changes in properties broaden the uses of starches by industries [7-12].

Considering the great variability of starch applications, the possibility of increasing the banana production sector for this purpose, and the hypothesis that the cultivation conditions may interfere not only in the increase of fruit production, but also in the phosphorylation process and, consequently, on the properties of the starch; the objective of this study was to evaluate the effect of levels of phosphate fertilization applied in cultivation of 'Maçã' banana on starch characteristics.

\section{Material and methods}

\subsection{Genotype characteristics}

The 'Maçã' bananas plant, belonging to the $A A B$ genotype group and the Prata subgroup, varies in size from 3.0 to $3.5 \mathrm{~m}$, with great tillering, a mean yield of $10 \mathrm{tha}^{-1}$ and a vegetative cycle of around 350 days. The mature fruits have thin, delicate peel and pale yellow color and are widely accepted in the domestic market. Its pulp is white, soft, and juicy, with a very pleasant taste. However, the fruits have little resistance to transportation and storage. The bunch is formed by approximately 86 fruits and 7 hands, with an average weight of $15 \mathrm{~kg}$. With length ranging from 10 to $16 \mathrm{~cm}$, its fruits are traditionally used in folk medicine as a regulator of bowel functioning. This genotype is moderately resistant to Yellow-Sigatoka and susceptive to Black-Sigatoka and Fusarium wilt $[4,13]$.

\subsection{Plant cultivation}

The bananas were cultivated at São Manuel Experimental Farm, São Paulo State University, São Paulo State, Brazil. Prior to the experiment, soil samples consisting of 20 subsamples was taken in the $0-0.20 \mathrm{~m}$ layer depth to determine the soil chemical properties (Table 1). Micro propagated 'Maçã' (AAB) banana plantlets were transplanted ( $4 \mathrm{~m}$ between rows and $2.5 \mathrm{~m}$ between plants). The experimental design was completely randomized with six doses of triple superphosphate $(0,40$, $60,80,100$ and $120 \mathrm{~kg} \mathrm{P}_{2} \mathrm{O}_{5} \mathrm{ha}^{-1}$ ) with seven replications. The experiment consisted of a total of 60 plants, where 42 plants were considered as useful and the others as border.

Phosphorus fertilization consisted of two applications: half of the six doses in the planting hole and the remainder at 80 days after planting in a circle of $100 \mathrm{~cm}$ diameter around the plants. In the course of the experiment were performed: irrigation, weed control, thinning and removal of dried leaves, fertilization, pest control and disease, elimination of banana heart, removal of pistils and cutting pseudostem after harvesting. The harvest of bunches occurred during the stage 1 of maturation of fruits (fully green peel).

Table 1

Basic characteristics of experimental conditions.

\begin{tabular}{|c|c|}
\hline Characteristics & Low P \\
\hline GPS & $\begin{array}{l}22^{\circ} 44^{\prime} 28^{\prime \prime} \mathrm{S} \\
48^{\circ} 34^{\prime} 37^{\prime \prime} \mathrm{W}\end{array}$ \\
\hline Above sea level (m) & 740 \\
\hline Soil classification & Dystrophic Red Latosol \\
\hline Clay Soil characteristics $(0-0,20 \mathrm{~m}$ of depth) & \\
\hline $\mathrm{pH}\left(1: 2.5 \mathrm{soil} / \mathrm{CaCl}_{2}\right.$ suspension $\left.0.01 \mathrm{~mol} \mathrm{~L}^{-1}\right)$ & 5.5 \\
\hline Organic matter $\left(\mathrm{g} \mathrm{dm}^{-3}\right)$ & 12 \\
\hline$P_{\text {resin-extractable }}\left(\mathrm{mg} \mathrm{dm}^{-3}\right)$ & 16 \\
\hline $\mathrm{K}\left(\mathrm{mmol}_{\mathrm{c}} \mathrm{dm}^{-3}\right)$ & 1 \\
\hline $\mathrm{Ca}\left(\mathrm{mmol}_{\mathrm{C}} \mathrm{dm}^{-3}\right)$ & 13 \\
\hline $\operatorname{Mg}\left(\mathrm{mmol}_{\mathrm{c}} \mathrm{dm}^{-3}\right)$ & 5 \\
\hline $\mathrm{H}+\mathrm{Al}\left(\mathrm{mmol}_{\mathrm{c}} \mathrm{dm}^{-3}\right)$ & 15 \\
\hline Cation exchange capacity $\left(\mathrm{mmol}_{\mathrm{c}} \mathrm{dm}^{-3}\right)$ & 34 \\
\hline Base saturation (\%) & 57 \\
\hline
\end{tabular}

\subsection{Extraction of starches}

The samples for qualitative examinations ( $10 \mathrm{~kg}$ of fruits) were collected from seven field replications for each plot by using standard methods. The fruits were peeled, sliced and crumbled in a stainless steel blender in solution of cold water $\left(4{ }^{\circ} \mathrm{C}\right)$ and ascorbic acid $(1 \%)$ for $60 \mathrm{~s}$ [4]. The suspension obtained was passed through 80 mesh $(0.177 \mathrm{~mm})$ and 100 mesh $(0.149 \mathrm{~mm})$ sieves for fiber removal. The residue retained in the 80 mesh sieve was mixed with water in a ratio of $1: 1$ (v: v), and ground for $60 \mathrm{~s}$ to remove the residual starch. The starch suspension recovered from the residue was mixed into the first suspension and kept in a cold room at $5{ }^{\circ} \mathrm{C}$ for $6 \mathrm{~h}$ for decantation of the starch. The starch was recovered by siphoning, washed with distilled water until the supernatant was cleaned, recovered by centrifugation and dried at $40{ }^{\circ} \mathrm{C}$ for $12 \mathrm{~h}$. The starches obtained after drying were milled in a mortar, passed through a 70 mesh $(0.212 \mathrm{~mm})$ sieve and stored in closed bottles at the refrigeration temperature for further analysis.

\subsection{Analysis of starches}

Starches from banana fruits grown at different levels of phosphate fertilization were analyzed for the morphology, X-ray diffraction pattern, relative crystallinity, granule size, amylose, resistant starch and phosphorus levels, as well as, for pasting properties and thermal properties of gelatinization and retrogradation.

\subsubsection{Morphology}

Scanning electron microscopy was used to analyze the morphology of starch granules. Scanning electron microscope (Quanta 200, FEI Company) was used under amperage of $80 \mathrm{~mA}$ and voltage of $12.5 \mathrm{kV}$. The powdered samples were sprinkled on double sided sticky stick tape placed on aluminum stubs and covered with a thin layer of gold in metallizer BAL-TEC SCD 050 for $220 \mathrm{~s}$.

\subsubsection{X-ray pattern and relative crystallinity}

The starches were preconditioned in desiccator containing saturated $\mathrm{BaCl}_{2}$ solution $\left(25^{\circ} \mathrm{C}\right.$, aw $\left.=0.9\right)$ for 10 days. The X-ray diffraction patterns of the samples were determined using an X-ray diffractometer (Rigaku Mini Flex 300, Tokyo, Japan) with $\mathrm{Cu}$ monochromatic radiation, line $\mathrm{K}, \mathrm{L}=1542 \AA$, using glass sample port. Samples were analyzed from $3^{\circ}$ to $40^{\circ}$ in $2 \theta$ with a scanning speed of $1^{\circ} / \mathrm{min}$ and the conditions of use were $30 \mathrm{kV}$ and $10 \mathrm{~mA}$. The relative crystallinity ( $R C$ \%) was estimated by the relation between the area of the peaks and the total area of the diffractograms [14].

\subsubsection{Granule size}

The granule size distribution was determined with laser diffraction using a Mastersizer 2000 (Malvern Instruments Ltd., Malvern, Worcestershire, UK) as described by Fu et al. [15] and Mesquita et al. [4].

\subsubsection{Phosphorus, amylose and resistant starch contents}

The phosphorus content was determined according to Smith and Caruso [16]. The amylose content of starch was determined using the method of Williams et al. [17] and resistant starch according to Goni et al. [18].

\subsubsection{Pasting properties}

The pasting properties of the starches were determined using a Rapid Visco Analyzer (RVA-4, Newport Scientific, Warriewood, Australia). Starch suspensions (10\% w/w, $27.5 \mathrm{~g}$ total) were placed in aluminum recipients and these coupled to the equipment. The conditions of the analyze were: the samples were kept at $50{ }^{\circ} \mathrm{C}$ for $1 \mathrm{~min}$; after this time were heated to $95{ }^{\circ} \mathrm{C}$ at a rate of $6{ }^{\circ} \mathrm{C} \mathrm{min}-1$ and remained at this temperature for $5 \mathrm{~min}$; then the samples were 
cooled to $50{ }^{\circ} \mathrm{C}$ also at a rate of $6{ }^{\circ} \mathrm{C} \mathrm{min}^{-1}$ and remained at this temperature until the end of the analysis (23 $\mathrm{min})$. Throughout the analyze the RVA kept the suspensions under stirring at $160 \mathrm{rpm}$. The Termoclines for Windows program, version 2.2 (Newport Scientific, Warriewood, Australia) was used to process the results [4].

\subsubsection{Thermal properties}

The thermal properties of the starches were determined using a Differential Exploration Calorimeter (DSC-Pyris 1, Perkin Elmer, Norwalk, USA). Samples of $4 \mathrm{mg}$ (dry basis) were weighed in aluminum sample port. Deionized water $(12 \mu \mathrm{L})$ was added and the containers were sealed in a universal press (Perkin Elmer, Norwalk, USA). The sealed containers were held for $12 \mathrm{~h}$ at room temperature and then heated at a rate of $10{ }^{\circ} \mathrm{C} \mathrm{min}-1$ at 25 to $125^{\circ} \mathrm{C}$. An empty aluminum sample port was used as a reference. The equipment was calibrated with indium. After running the samples in DSC, they were refrigerated at $5{ }^{\circ} \mathrm{C}$ for 14 days and analyzed again under the same conditions to determine the thermal properties of retro-graded starches. The transition temperatures (initial, peak and final) and the enthalpy change $(\Delta \mathrm{H})$ of the gelatinized and retrograded samples were determined using Pyris 1 software (Perkin Elmer, Norwalk, USA) [4].

\subsection{Statistical analysis}

The data were submitted to analysis of variance and when there was a significant effect for phosphorus doses, according to the test $\mathrm{F}$ at $5 \%$ probability $(p<0.05)$, the regression analysis was performed aiming to verify the effect of phosphate fertilization on the evaluated characteristics.

\section{Results and discussion}

\subsection{Morphological characteristics}

The morphological characteristics of starches from different conditions of phosphate fertilizer was analyzed using SEM and represented in Fig. 1.

Regardless of the phosphate fertilization conditions used in the 'Maçã' banana crop, the starches extracted from the fruits presented elongated flattened forms, predominating oval and rod shapes, with smooth surfaces and with varying sizes. It was not possible to detect changes in the form of the granules for the different levels of phosphate application in the culture. These shapes has been observed in morphological analyses of banana starches, with small differences in description of predominant shape (oval, rod, long rod) which may be affected by genetic variation $[19,20]$.

\subsection{Phosphorus}

Phosphorus content in starch from 'Maçã' banana ranged from 0.007 to $0.018 \%$. These contents are lower than those reported by Enggleston et al. [21] in plantains starch and similar to that found in starches extracted from bananas cultivated in Brazil [4].

The increase in the rates of phosphate fertilization applied in the banana crop promoted increasing in the phosphorylation of the starch, with a tendency to decrease in higher levels of $\mathrm{P}_{2} \mathrm{O}_{5}$ applied (Table 2, Fig. 2a). Similar result was related by Jacobsen et al. [7]. This authors studying phosphate fertilization in potato observed that the crop yield was not affected by the rate of P-fertilizer applied; however, there was a significant increase in the level of phosphorylation of the starch with increasing amount of P-fertilizer applied to the soils.

This result can be associated to the phosphorus availability in the soil. Jain et al. [22] in their study with kinetics of phosphorus absorption cited that the mechanisms of high and low affinity are involved with the concentration of the nutrient in the soil. At low phosphorus availability, high affinity transporters are activated, ensuring the entry of phosphorus into the cells, on the other hand, when the phosphorus is highly available in the soil the low affinity transporters are expressed. Applying higher rates of phosphate fertilizer may result in considerable immobilisation, leaving part of the phosphate inaccessible to the plants [7].

Besides this, starch biosynthesis requires the action of a range of enzymes: ADP-glucose pyrophosphorylase - catalyses the first step of starch biosynthesis; starch synthesis - responsible for chain elongation; starch-branching enzymes - catalyze chain-transfer reactions and hydrolytic activities [23]. The phosphorus has important function in starch synthesis. The ADP-glucose pyrophosphorylase is inhibited by inorganic phosphorus ( $\mathrm{Pi}$ ) and stimulated by triose phosphate (TF) [24], i.e. changes in phosphorus availability in the soil can interfere in synthesis of starch in banana plant.

\subsection{X-ray pattern and cristallinity}

Analysis of X-ray diffraction showed that independent of the growth conditions 'Maçã' banana starches showed B-type crystalline pattern (Fig. 2b); however, the intensities of the peaks were different. This result suggested that the organization of starch polymers does not change under different phosphorus level.
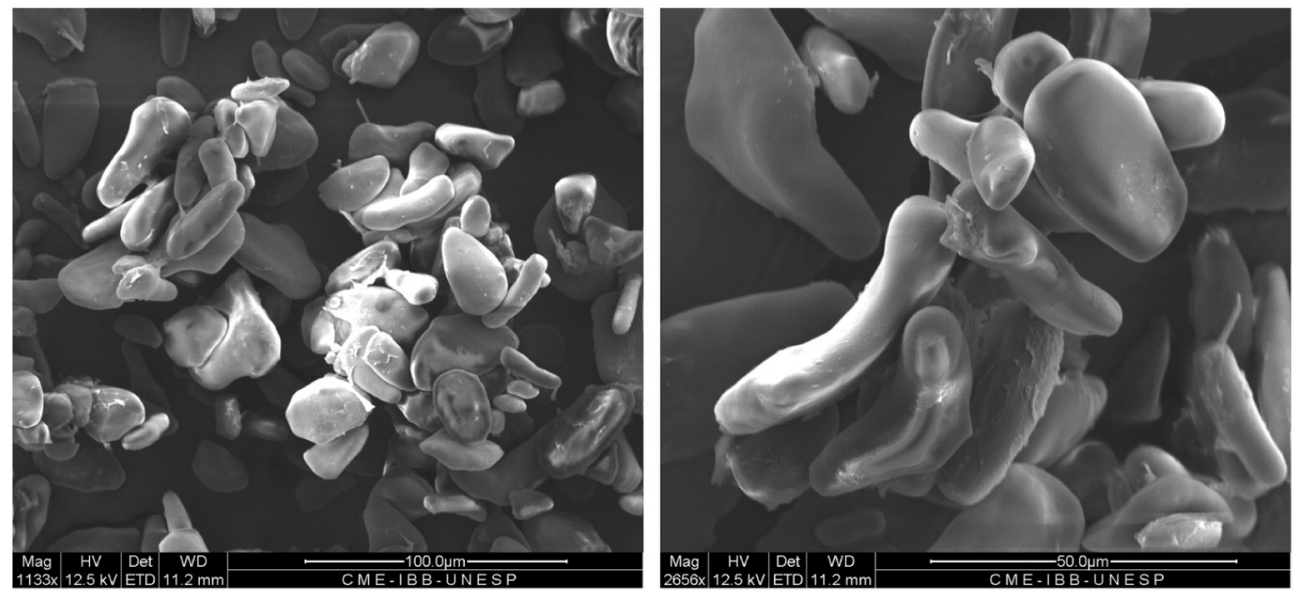

Fig. 1. Morphology of granules of starches obtained from 'Maçã' banana. 
Table 2

Characteristics of starches of banana cv Maçã in function of phosphate fertilizer rates.

\begin{tabular}{|c|c|c|c|c|c|c|c|c|}
\hline \multirow[t]{2}{*}{ Variables } & \multicolumn{5}{|c|}{$\mathrm{P}_{2} \mathrm{O}_{5}\left(\mathrm{Kg} \mathrm{ha}^{-1}\right)$} & \multirow[t]{2}{*}{ F value } & \multirow[t]{2}{*}{ Regression equation } & \multirow[t]{2}{*}{$\mathrm{R}^{2}$} \\
\hline & 0 & 40 & 80 & 100 & 120 & & & \\
\hline Phosphorus (\%) & 0,007 & 0,018 & 0,015 & 0,013 & 0,010 & $87.73^{* * *}$ & $Y=0.007+0.0003 \times-0.000003 \times{ }^{2}$ & 0.869 \\
\hline Crystallinity (\%) & 32,15 & 29,31 & 29,09 & 28,5 & 27,42 & $46.6^{* * *}$ & $\mathrm{Y}=31.63-0.044 \times$ & 0.893 \\
\hline Granule size $(\mu \mathrm{m})$ & 41,88 & 59,26 & 47,17 & 45,30 & 41,85 & $186.8^{* * *}$ & $Y=43.33+0.419 \times-0.004 \times{ }^{2}$ & 0.620 \\
\hline Amylose (\%) & 29,01 & 30,62 & 30,55 & 31,12 & 30,71 & $8.57^{* *}$ & $Y=29.02+0.048 \times-0.0003 \times{ }^{2}$ & 0.947 \\
\hline Resistant starch (\%) & 67,54 & 65,16 & 63,97 & 62,78 & 61,59 & $131.5^{* * *}$ & $Y=67.54-0.0595 \times$ & 0.783 \\
\hline \multicolumn{9}{|l|}{ Pasting properties } \\
\hline Peak viscosity (RVU) & 371,70 & 279,07 & 303,05 & 314,65 & 319,65 & $75.71^{* * *}$ & $Y=366.79-2.56 \times+0.022 \times{ }^{2}$ & 0.823 \\
\hline Breakdown (RVU) & 122,27 & 96,05 & 104,30 & 103,85 & 114,57 & $17.50^{* * *}$ & $Y=121.39-0.82 \times+0.007 \times{ }^{2}$ & 0.889 \\
\hline Final Viscosity (RVU) & 445,72 & 332,80 & 377,17 & 372,27 & 394,77 & $37.71^{* * *}$ & $Y=439.83-3.06 \times+0.027 \times{ }^{2}$ & 0.781 \\
\hline Setback (RVU) & 196,27 & 152,27 & 178,42 & 161,50 & 189,75 & $52.64^{* * *}$ & $Y=194.7-1.28 \times+0.012 \times^{2}$ & 0.656 \\
\hline \multicolumn{9}{|l|}{ Thermal properties } \\
\hline $\mathrm{T}_{\mathrm{o} \text { gel }}\left({ }^{\circ} \mathrm{C}\right)$ & 70,22 & 67,50 & 69,65 & 71,10 & 69,37 & $87.64^{* * *}$ & $Y=70.22-0.30 \times+0.007 \times{ }^{2}-0.00005 \times{ }^{3}$ & 0.999 \\
\hline $\mathrm{T}_{\mathrm{p} \text { gel }}\left({ }^{\circ} \mathrm{C}\right)$ & 73,15 & 71,35 & 72,27 & 73,92 & 72,75 & $28.73^{* * *}$ & $Y=73.17-0.21 \times+0.005 \times{ }^{2}-0.00003 \times{ }^{3}$ & 0.941 \\
\hline $\mathrm{T}_{\text {e gel }}\left({ }^{\circ} \mathrm{C}\right)$ & 76,35 & 74,60 & 75,15 & 77,62 & 75,80 & $56.62^{* * *}$ & $Y=76.39-0.23 \times+0.006 \times^{2}-0.00004 \times{ }^{3}$ & 0.808 \\
\hline$\Delta \mathrm{H}_{\text {gel }}\left(\mathrm{J} \mathrm{g}^{-1}\right)$ & 11,62 & 9,80 & 10,7 & 10,32 & 12,32 & $101.3^{* * *}$ & $Y=11.61-0.07 \times+0.0007 \times^{2}$ & 0.838 \\
\hline $\mathrm{T}_{\text {o ret }}\left({ }^{\circ} \mathrm{C}\right)$ & 57,55 & 43,90 & 44,45 & 45,30 & 48,75 & $761.5^{* * *}$ & $Y=57.27-0.45 \times+0.003 \times^{2}$ & 0.978 \\
\hline $\mathrm{T}_{\text {p ret }}\left({ }^{\circ} \mathrm{C}\right)$ & 63,1 & 53,60 & 55,45 & 53,92 & 54,42 & $365.7^{* * *}$ & $Y=62.72-0.25 x+0.0017 \times^{2}$ & 0.901 \\
\hline $\mathrm{T}_{\text {e ret }}\left({ }^{\circ} \mathrm{C}\right)$ & 67,57 & 59,35 & 59,17 & 62,70 & 67,47 & $574.1^{* * *}$ & $Y=67.53-0.33 \times+0.003 x^{2}$ & 0.995 \\
\hline$\Delta \mathrm{H}_{\text {ret }}\left(\mathrm{J} \mathrm{g}^{-1}\right)$ & 7,95 & 2,47 & 4,17 & 6,95 & 7,70 & $715.2^{* * *}$ & $Y=7.60-0.168 \times+0.002 \times^{2}$ & 0.806 \\
\hline
\end{tabular}

Li et al. [25] studying the effect of different phosphorus $\left(\mathrm{P}_{2} \mathrm{O}_{5}\right)$ levels applied in cultivation of winter wheat observed that the starches from two cultivars and three phosphorus levels displayed typical A-type patterns and that, although there were no differences between peak positions, small differences were observed in intensities of all finger print peaks.

The B-type pattern of banana starch had been cited in other studies [26-28]. In B-pattern, amylopectin has less branching and long chains associated with amylose molecules. It has two groups of double helices in the unit cell and adopts a more open organization between the macromolecules, with a water column present between the arrangement of the double helices of amylopectin [29].

Zhang and Hamarker [30] in their study with banana starch cited that banana amylopectin displays a lower proportion of short chains DP 6-12 (21.6\%) and higher proportion oflong chains DP > 36 (21.4\%).

Phosphorylation of the starch is part of the biosynthesis process and the starch is phosphorylated in some of its glucose residues at the C-3 and C-6 positions. This process is performed by the enzymes glucan water dikinase (GWD) and phosphoglucan water dikinase (PWD). GWD specifically phosphorylates $C-6$ positions while PWD recognizes pre-phosphorylated C-6 and subsequently phosphorylates C-3 hydroxyl group. The majority of the phosphate is bound in the amylopectin and mainly to thelonger unit chains [31-33].

Data analysis showed effect of fertilization on the cristallinity of the starch. The increase in phosphorus fertilizer led to a decreasing of cristallinity of the starches (Table 2, Fig. 2c). These changes are due the phosphate substitution in amylopectin structure. The free C-3 and C-6 hydroxyl groups of the glucose units are located on the hydrophilic surface of the double helix and it will be align or protrude from the helix surface affecting the stability or side packaging, and thus interfering with the crystallinity of the starch. It was described that the effect of starch phosphate on crystallinity result more from C-3 phosphorylation than from C-6 [23].

\subsection{Granule size}

In general, starches from different banana genotypes show oval and elongated shapes with major diameter ranging from 6 to $80 \mu \mathrm{m}$, mostly between 20 and $60 \mu \mathrm{m}[4,28]$.
Granule sizes of banana ranged from 41.85 to $59.26 \mu \mathrm{m}$ and the analysis of the data showed a significant effect of levels of phosphate fertilization on the average size of the starch granules. The application of phosphate fertilizer initially promoted the increase of the average size of the granules with a tendency to decrease in the conditions of higher levels of fertilizer (Table 2, Fig. 2d).

This variation in the size of the granules may be due to the fact that the phosphate groups introduced in the starch chains cause repulsion between phosphate groups on adjacent chains increasing hydration of the granule and thus increasing granule size. On the other hand, this effect can also associate with the effect of phosphate fertilization on activity of the enzymes of the starch biosynthesis process.

Li et al. [25] in their study about the effects of phosphate fertilization on the characteristics of wheat starch report holes in the surface of the starch granules extracted from wheat grown with high rate of phosphate fertilizer, as well as, modification in the granule size distribution, suggesting that the presence of the holes resulted from the unbalanced level of starch synthase and hydrolase and induced the premature autolysis of the granules.

\subsection{Amylose}

The amylose content of banana starch ranged from 29.01 to $31.12 \%$ with significant effect of rates of phosphate fertilization (Table 2 , Fig. 2e) on this polymer. This variation can also be related to the effect of the growth conditions on the activity of the enzymes of the starch biosynthesis.

Some studies have reported that the amylose content is proportional to the size of the granules and that these are directly related to the activity of the starch synthase (GBSS-I) [34-36]. Thus, the higher availability of phosphorus in the soil contributed to the enzymatic activity of amylose synthesis; however, in the higher rates this effect was not so significant due to the mechanisms of control of phosphorus transport in the plant $[7,22]$.

\subsection{Resistant starch}

Resistant starch (RS) is the fraction of total starch that is not digested or absorbed in the small intestine and has a physiological function similar to that of fibers. It can delay blood glucose and 


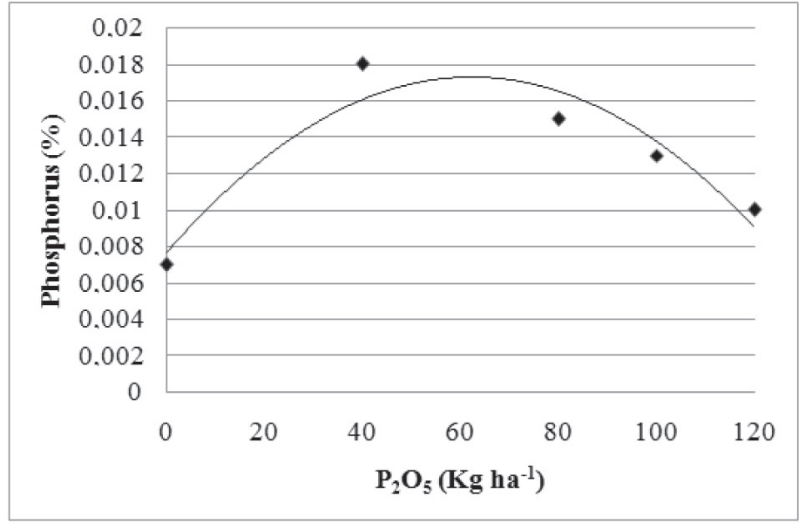

a

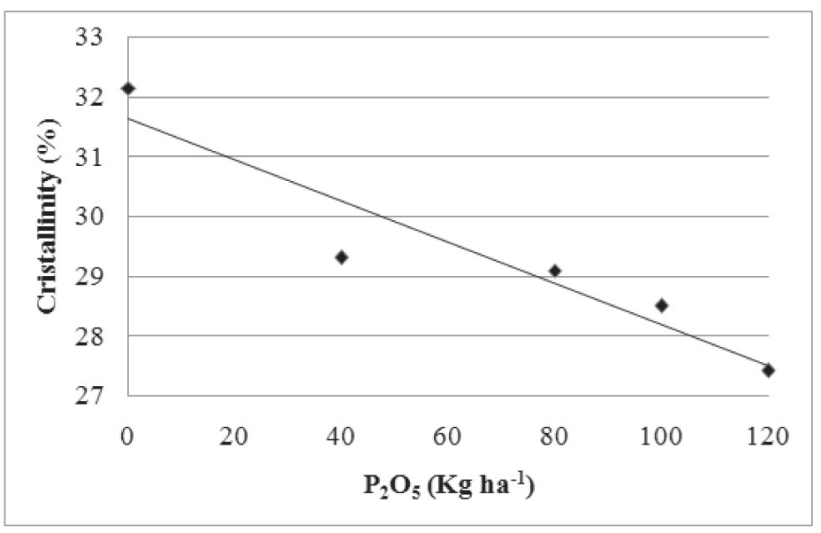

C

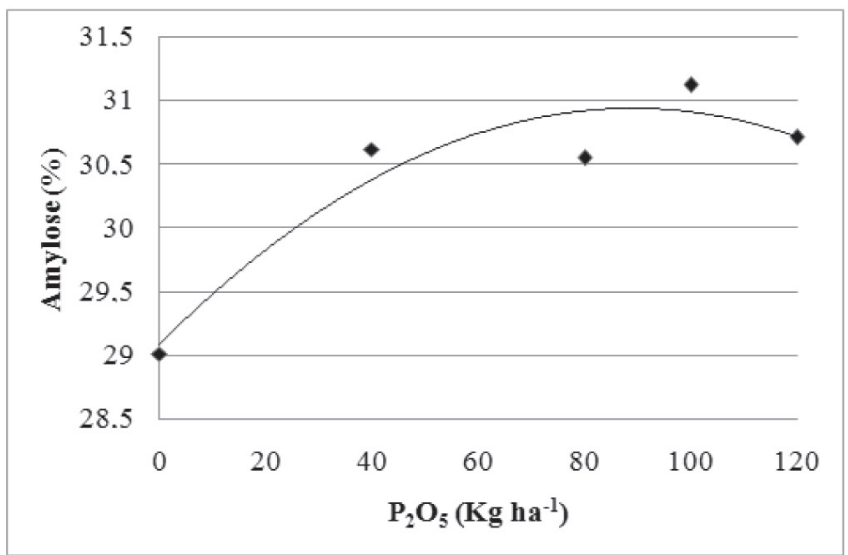

d

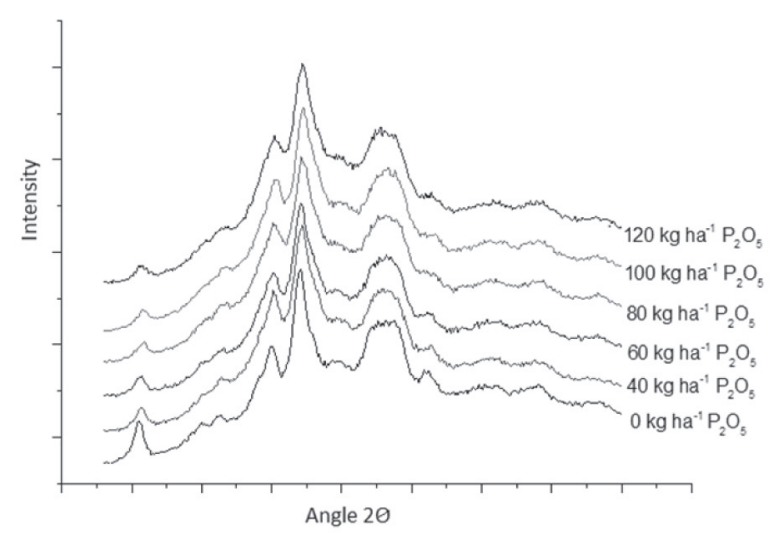

b

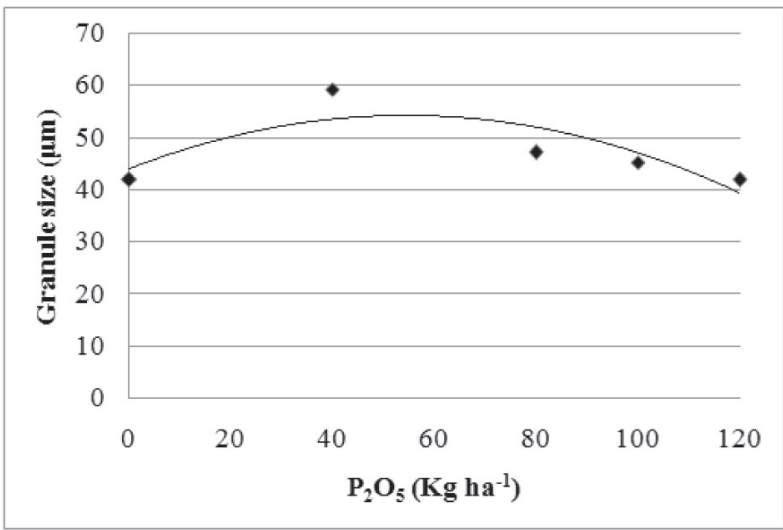

d

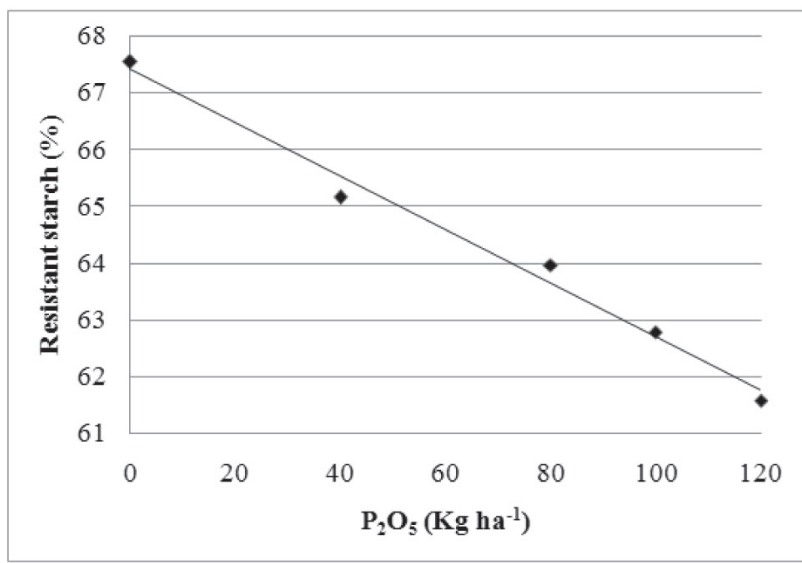

f

Fig. 2. Phosphorus (\%), X-ray pattern, crystallinity (\%), granule size ( $\mu \mathrm{m})$, amylose (\%) and resistant starch of 'Maçã' banana starch as a function of $\mathrm{P}_{2} \mathrm{O}_{5}$ application rates.

insulin response, and reduce the concentration of cholesterol and triglycerides. Besides this, resistant starch may play an important role in the prevention of colon cancer [37,38].

Data analysis showed interference of $\mathrm{P}_{2} \mathrm{O}_{5}$ fertilizer on the resistant starch content (Table 2). The increase of levels of phosphate fertilizer used in cultivation of banana 'Maçã' led a decrease of percentage of RS (Fig. 2f).

The rates of fertilizer also affected other important parameters related with digestibility of the starch. Starch granule structure and interactions between the granule and other components can affect the starch digestibility. Starch with higher crystallinity shows lower digestion rates, and besides this, high content of long-chain amylopectin is associated with lower degradation rates [39-41].

\subsection{Pasting and thermal properties}

Starch granules are insoluble in cold water but when heated in excess of water they swell irreversibly (gelatinization), losing crystallinity and structural organization and producing a viscous paste [42].

Data analysis of pasting properties of starches extracted from banana 'Maçã' growth in different conditions of fertilization showed quadratic effect of fertilizer rates on all viscosity parameters (Table 2). The increase of levels of $\mathrm{P}_{2} \mathrm{O}_{5}$ used during banana cultivation (until $80 \mathrm{~kg} \mathrm{ha}^{-1}$ ) led to obtaining of starches with lower peak viscosity, breakdown, final viscosity and retrogradation tendency (Fig. 3a to d), similar properties than phosphate starches modified 


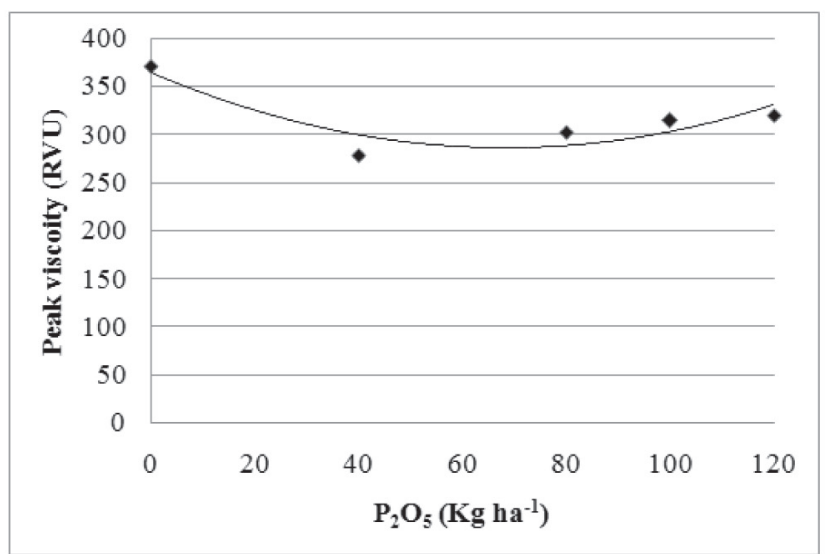

$\mathrm{a}$

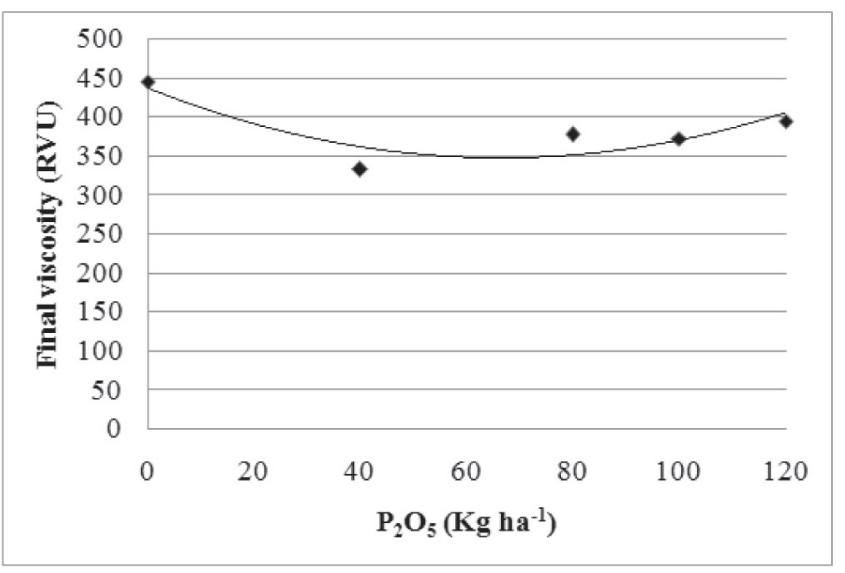

C

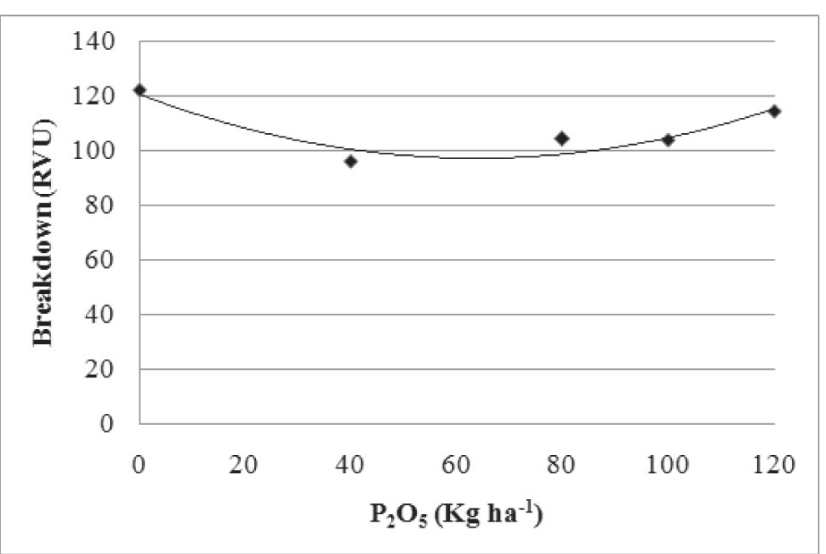

$\mathrm{b}$

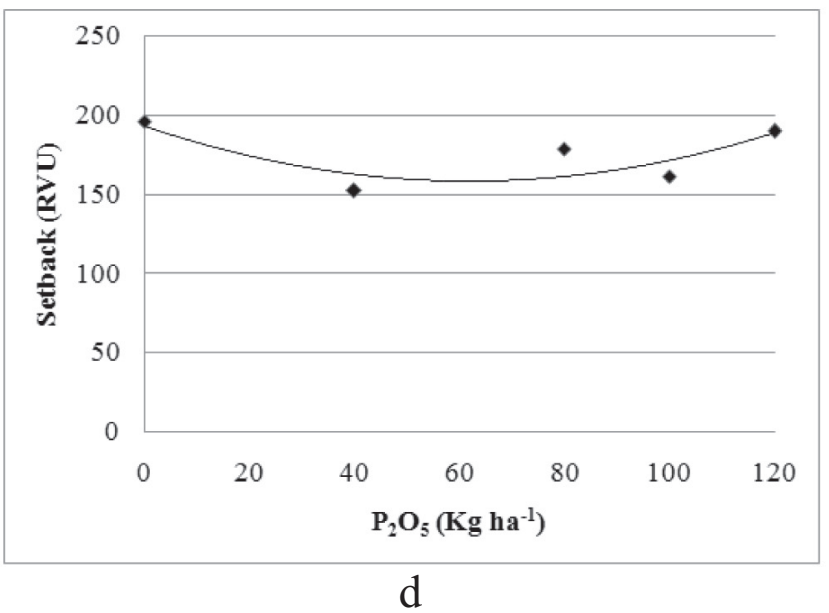

Fig. 3. Pasting properties of 'Maçã' banana starch as a function of $\mathrm{P}_{2} \mathrm{O}_{5}$ application rates.

chemically. These changes may be a result of the increase in the number of phosphate groups attached to the starch which progressively weakens the granular structure. That is, the decrease in viscosity may be related to the decrease in the number of hydrogen bonds between hydroxyl groups between the starch molecules [43]. The significant decrease of seatback with use of phosphate fertilizer (40 kg ha ${ }^{-1}$ ) indicates that phosphorus linked in starch inhibited the rearrangement of chains.

The analysis of the thermal properties of the starches showed a significant effect of the fertilization conditions on the initial, peak and final gelatinization temperatures, as well as on enthalpy (Table 2, Fig. 4a to d). A decrease in the gelatinization and enthalpy temperatures was observed with the use of phosphate fertilization $\left(40 \mathrm{~kg} \mathrm{ha}^{-1}\right)$ and the increase in the fertilize rates led to a small increase with tendency to stabilization.

The changes in phosphorus levels in starch can have promoted the disruption of the hydrogen bonds of the amylopectin double helix reducing the crystalline region of the starches with consequent changes in gelatinization temperatures and enthalpy. Low transition temperatures correspond to a low degree of crystallinity, providing lower structural stability and granule with reduced resistance to the gelatinization process. Besides, the enthalpy range is negatively correlated with phosphorus, requiring less energy for transition of granular starch from crystalline to amorphous state, according to increase levels of phosphorus in starch [43-45].

The analysis of the thermal properties of retrogradation showed decrease of the temperatures and the enthalpy, independent of the culture conditions (Table 2, Fig. 4 e to $4 \mathrm{i}$ ). This reduction occurs because of an improper alignment of amylopectin chains during reassociation. In addition, a significant effect of phosphate fertilizer levels was observed on all parameters of thermal retrogradation properties, with a positive quadratic effect on $T_{0}, T_{p}, T_{e}$ and $\Delta H$, and positive linear effect on $\Delta \mathrm{T}$.

\section{Conclusion}

The use of $\mathrm{P}_{2} \mathrm{O}_{5}$ fertilizer in the cultivation of 'Maçã' banana leads to changes in crystallinity, granule size, contents of phosphorus, amylose and resistant starch, as well as, in paste and thermal properties of the starches. The application of $40 \mathrm{~kg} \mathrm{ha}^{-1}$ of $\mathrm{P}_{2} \mathrm{O}_{5}$ allows a greater incorporation of phosphorus in the starch molecule thus promoting pronounced changes when compared to the starch extracted from bananas cultivated without the use of fertilizer. However, the increase in rates of fertilizer leads to different changes in starches characteristics.

\section{Conflict of interest}

The authors declare no conflict of interest.

\section{Author contributions}

The manuscript was written through contributions of all authors. All authors have given approval to the final version of the manuscript.

\section{Acknowledgements}

The authors acknowledge the financial support from the CNPq (Proc. 303373/2014-8 and 304571/2013-0). 


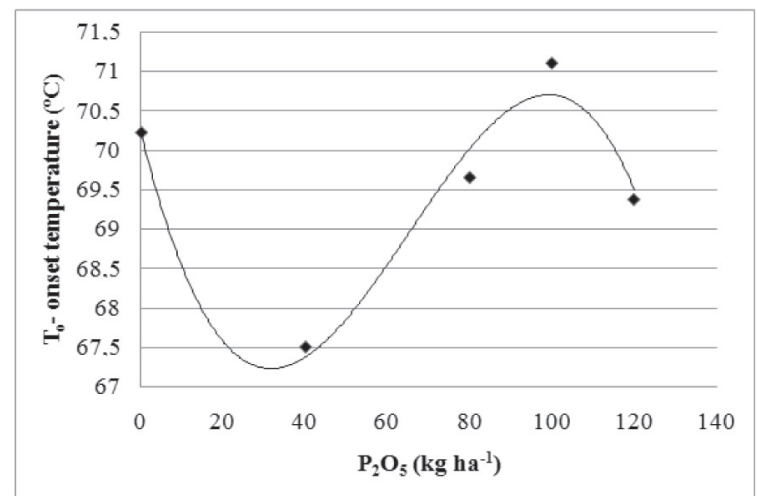

a

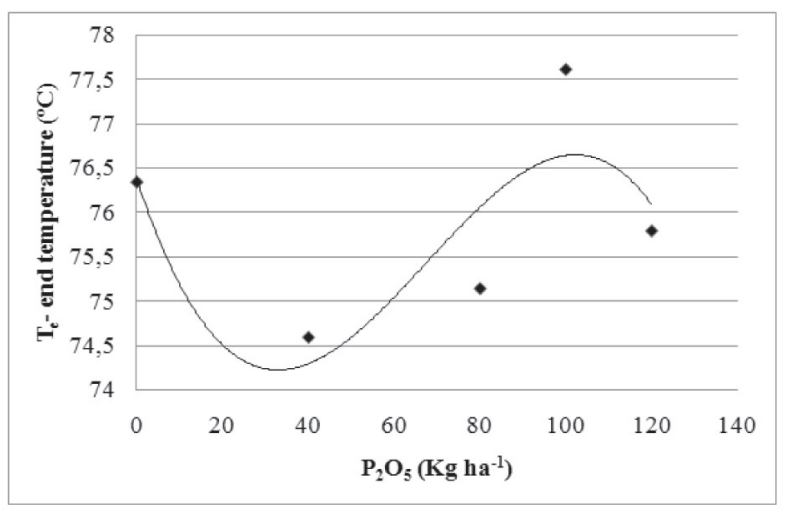

C

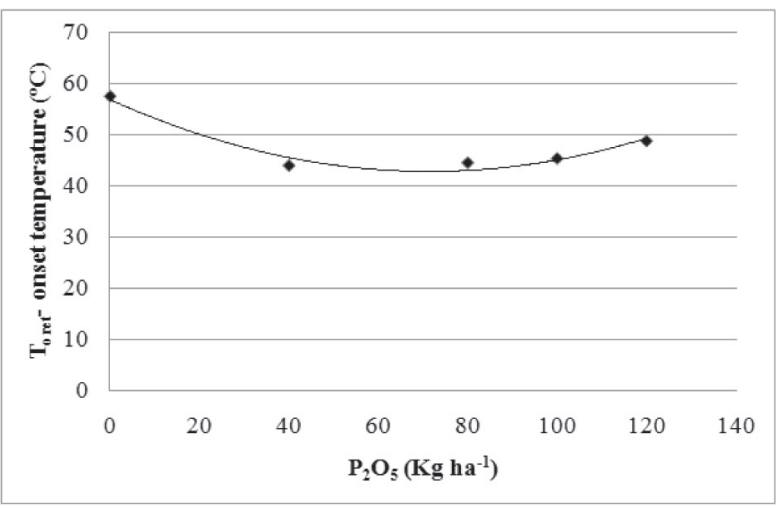

e

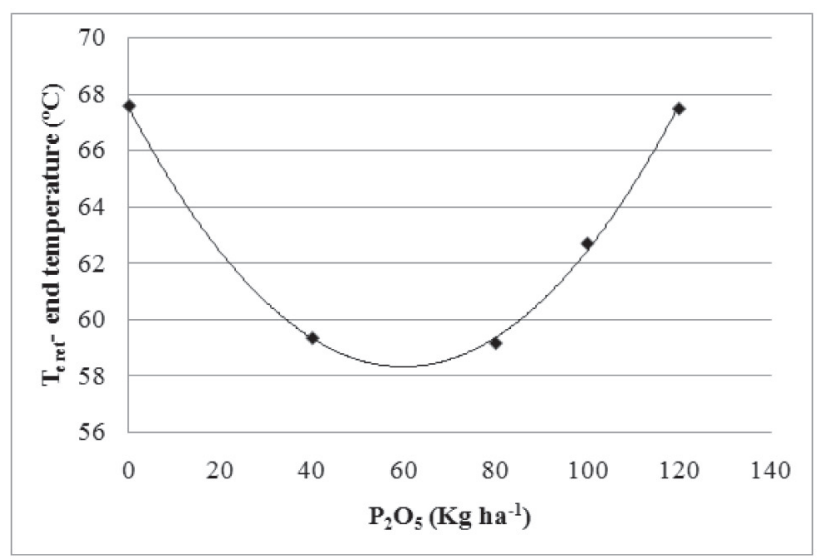

g

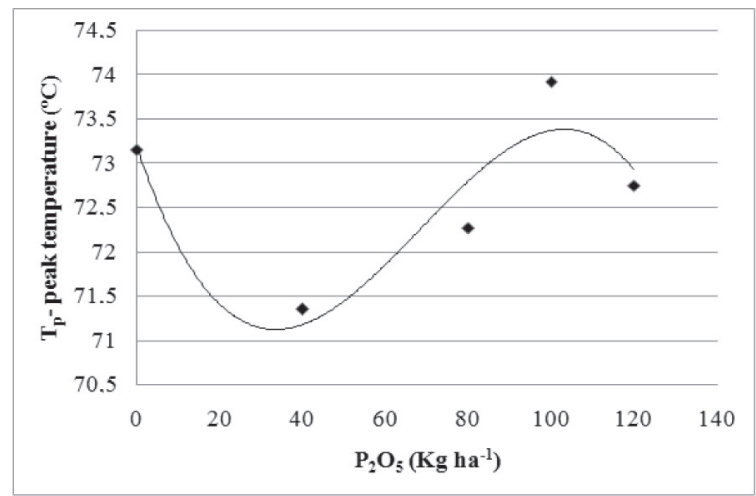

b

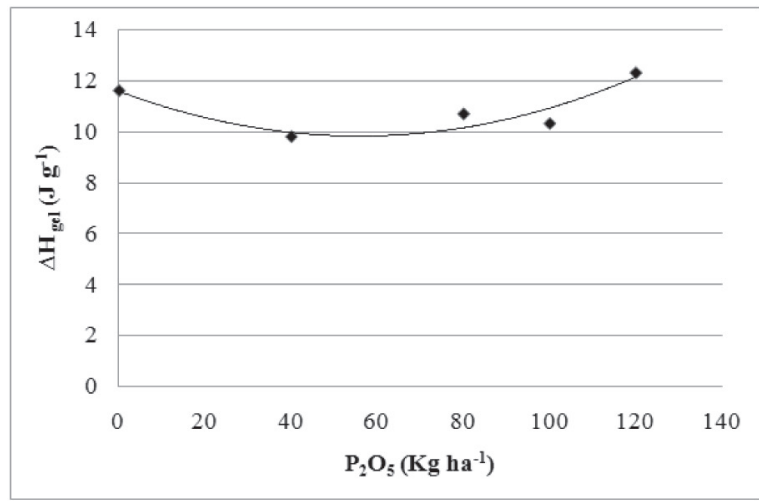

d

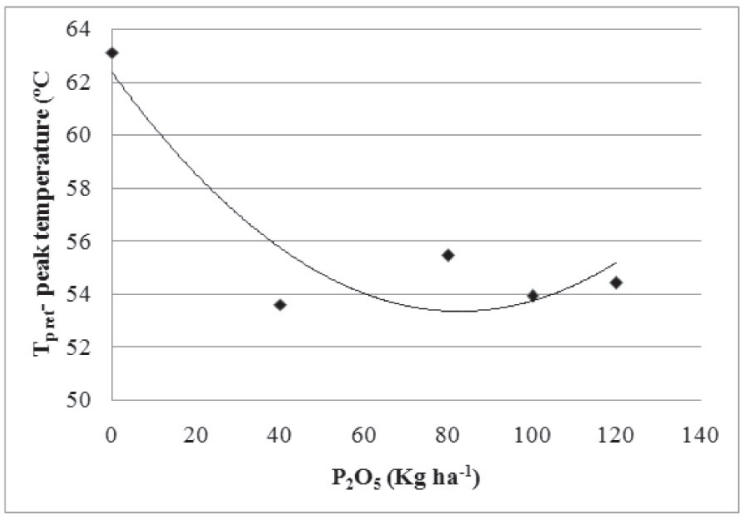

f

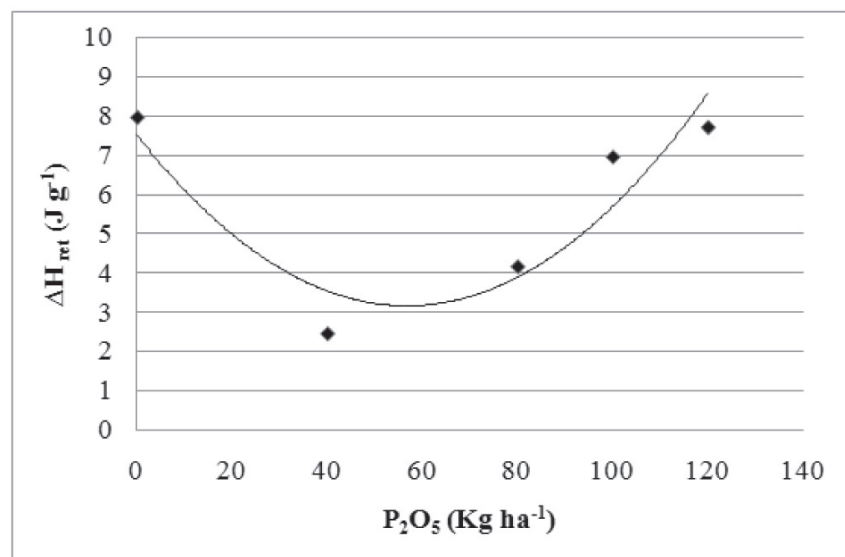

h

Fig. 4. Thermal properties of 'Maçã' banana starch as a function of $\mathrm{P}_{2} \mathrm{O}_{5}$ application rates (gelatinization properties: a, b, c, d and retrogradation properties: e, f, g, h). 


\section{References}

[1] FAO - Food and Agriculture Organization, Production crop data, http://faostat3.fao. org/browse/Q/QC/E 2014 (accessed 17 Oct 2017).

[2] J. Silveira, H. Galeskas, R. Tapetti, I. Lourencini, Quem é o consumidor brasileiro de frutas e hortaliças, 2011 8-23 (Hortifruti Brasil).

[3] B. Singh, J.P. Singh, A. Kaur, N. Singh, Bioactive compounds in banana and their associated health benefits - a review, Food Chem. 206 (2016) 1-11.

[4] C.B. Mesquita, M. Leonel, C.M.L. Franco, S. Leonel, E.L. Garcia, T.P.R. Santos, Characterization of banana starches obtained from cultivars grown in Brazil, Int. J. Biol. Macromol. 89 (2016) 632-639.

[5] C.A. Grant, D.N. Platen, D.J. Tomaziewicz, S.C. Sheppard, A importância do fósforo no desenvolvimento inicial da planta, Informações Agronômicas 95 (2001).

[6] J.T.A. Silva, M.G.V. Rodrigues, Produção da bananeira 'Prata Anã' em função da aplicação de adubo fosfatado em quatro ciclos, Pesq Agropec Bras. 48 (6) (2013) 613-618.

[7] H.B. Jacobsen, M.H. Madsen, J. Christiansen, T.H. Nielsen, The degree of starch phosphorylation as influenced by phosphate deprivation of potato (Solanum tuberosum L.) plants, Potato Res. 41 (1998) 109-116.

[8] J.L. Jane, Y.Y. Chen, L.F. Lee, A.E. McPherson, K.S. Wong, M. Radosavljevic, T. Kasemsuwan, Effects of amylopectin branch chain length and amylose content on the gelatinization and pasting properties of starch, Cereal Chem. 78 (1999) 629-637.

[9] T. Yoneya, K. Ishibashi, K. Hironaka, K. Yamamoto, Influence of cross-linked potato starch treated with $\mathrm{POCl} 3$ on DSC, rheological properties and granule size Carbohydr. Polym. 53 (2003) 447-457.

[10] T. Noda, N.S. Kottearachchi, S. Tsuda, M. Mori, S. Takigawa, C. Matsuura-Endo, S.] Kim, N. Hasimoto, H. Yamauchi, Starch phosphorus content in potato (Solanum tuberosum L.) cultivars and its effect on other starch properties, Carbohydr. Polym. 68 (2007) 793-796.

11] Z-L. Lu, R.Y. Yada, Q Liu, B. Bizimungu, A Murphy, D. De Koeyer, X-Q Li, R.G. Pinhero, Correlation of physicochemical and nutritional properties of dry matter and starch in potatoes grown in different locations, Food Chem. 126 (2011) 1246-1253.

[12] M. Leonel, E.L. Carmo, A.M. Fernandes, C.M.L. Franco, R.P. Soratto, Physicochemical properties of starches isolated from potato cultivars grown in soils with different phosphorus availability, J. Sci. Food Agric. 96 (2016) 1900-1905.

[13] S.O. Silva, J.A. Santos-Serejo, Z.J.M. Cordeiro, Variedades, in: A.L. Borges, L.S. Souza (Eds.),O cultivo da bananeira, Cruz das Almas, Embrapa Mandioca e Fruticultura 2004, pp. 45-58.

[14] S. Nara, T. Komiya, Studies on the relationship between water-satured state and crystallinity by the diffraction method for moistened potato starch, Starch/Stärke 35 (12) (1983) 407-410.

[15] Z.G. Fu, L.J. Wang, D. Li, B. Adhikari, Effects of partial gelatinization on structure and thermal properties of corn starch after spray drying, Carbohydr. Polym. 88 (4) (2012) 1319-1325.

[16] A.R. Smith, T.E. Caruso, Determination of phosphorous content, in: R.L. Whistler (Ed.), Methods in Carbohydrate Chemistry, 4, Academic Press, New York 1964 pp. 43-47 (Starch. Ed.).

[17] P.C. Williams, F.D. Kuzina, L. Hlynka, A rapid calorimetric procedure for estimating the amylose content of starches and flour, Cereal Chem. 47 (4) (1970) 411-420.

[18] I. Goni, A. Garcia-Alonso, F. Saura-Calixto, A starch hydrolysis procedure to estimate glycemic index, Nutr. Res. 17 (3) (1997) 427-437.

[19] J.L. Jane, T. Kasemsuwan, S. Leas, H. Zobel, J.F. Robyt, Anthology of starch granule morphology by scanning electron microscopy, Starch-Starke 46 (1994) 121-129.

[20] R. Utrilla-Coello, M. Rodríguez-Huezo, H. Carrillo-Navas, C. Hernández-Jaimes, E. Vernon-Carter, J. Alvarez-Ramirez, In vitro digestibility, physicochemical, thermal and rheological properties of banana starches, Carbohydr. Polym. 101 (2014) 154-162.

[21] G. Eggleston, R. Swennen, S. Akoni, Physicochemical studies on starches isolated from plantain cultivars, plantain hybrids and cooking bananas, Starch/Stärke 44 (1992) 121-128

[22] A. Jain, M.J. Vasconcelos, K.G. Raghothama, S.V. Sahi, Molecular mechanisms of plant adaptation to phosphate deficiency, Plant Breeding Reviews, 29, 2007, pp. 359-419.
[23] A. Blennow, A.M. Bay-Smidt, C.E. Olsen, B.L. Møller, The distribution of covalently bound phosphate in the starch granule in relation to starch crystallinity, Int. J. Biol. Macromol. 27 (2000) 211-218.

[24] V. Faquin, Nutrição Mineral de Plantas, UFLA/FAEPE, Lavras, 2005.

[25] C.Y. Li, C. Li, R.Q. Zhang, W. Liang, Effect of phosphorus on the characteristics of starch in winter wheat, Starch 65 (2013) 801-807.

[26] N. Faisant, A. Buleon, P. Colonna, C. Molis, S. Lartigue, J.P. Galmiche, M. Champ, Digestion of raw banana starch in the small intestine of healthy humans: structural features of resistant starch, Br. J. Nutr. 73 (01) (1995) 111-123.

[27] T. Tongdang, T. Saasagul, Some properties of banana starches extracted from two varieties, Conference on Starch Technology, Bangkok/Thailand, Proceedings of Starch Update 2005, pp. 199-200.

[28] P. Zhang, R.L. Whistler, J.N. BeMiller, B.R. Hamaker, Banana starch: production, physicochemical properties, and digestibilityda review, Carbohydr. Polym. 59 (4) (2005) 443-458.

[29] O.J. Gallant, B. Bouchet, A. Búleon, S. Perez, Physical characteristics of starch granules and susceptibility to enzymic degradation, Eur. J. Clin. Nutr. 46 (Suppl. 2) (1992) S3-S16.

[30] P. Zhang, B.R. Hamaker, Banana starch structure and digestibility, Carbohydr. Polym. 87 (2012) 1552-1558.

[31] G. Ritte, M. Steup, J. Kossmann, J.R. Lloyd, Determination of the starchphosphorylating enzyme activity in plant extracts, Planta 216 (2003) 798-801.

[32] O. Kötting, K. Pusch, A. Tiessen, P. Geigenberger, M. Steup, G. Ritte, Identification of a novel enzyme required for starch metabolism in Arabidopsisleaves. The phosphoglucan, water dikinase, Plant Physiol. 137 (2005) 242-252.

[33] J. Wikman, A. Blennow, A. Buleon, J.-L. Putaux, S. Perez, K. Seetharaman, E. Bertoft, Influence of amylopectin structure and degree of phosphorylation on the molecular composition of potato starch lintners, Biopolymers 101 (3) (2013) 257-271.

[34] D.D. Pan, J. Jane, Internal structure of normal maize starch granules revealed by chemical surface gelatinization, Biomacromolecules 1 (2000) 126-132.

[35] R.G. Utrilla-Coello, E. Agama-Acevedo, A.P. Barba de la Rosa, S.L. Rodríguez-Ambriz, L.A. Bello-Pérez, Physicochemical and enzyme characterization of small and large starch granules isolated from two maize cultivars, Cereal Chem. 87 (1) (2010) 50-56.

[36] C. Wang, C.-H. Tang, X. Fu, Q. Huang, B. Zhang, Granular size of potato starch affects structural properties, octenylsuccinic anhydride modification and flowability, Food Chem. 212 (2016) 453-459.

[37] E. Fuentes-Zaragoza, M. Riquelme-Navarrete, E. Sánchez-Zapata, J. Pérez-Álvarez, Resistant starch as functional ingredient: a review, Food Res. Int. 43 (2010) 931-942.

[38] H. Gao, S. Huang, T. Dong, Q. Yang, G. Yi, Analysis of resistant starch degradation in postharvest ripening of two banana cultivars: focus on starch structure and amylases, Postharvest Biol. Technol. 119 (2016) 1-8.

[39] S. Srichuwong, T.C. Sunarti, T. Mishima, N. Isono, M. Hisamatsu, Starches from different botanical sources I: contribution of amylopectin fine structure to thermal properties and enzyme digestibility, Carbohydr. Polym. 60 (4) (2005) 529-538.

[40] J. Gu, Physicochemical Properties and Digestibility of Buch Wheat Starch. Unpublished Dissertation for the Degree of Master, Jiangnan University, 2009.

[41] Y. Bi, Y. Zhang, H. Jiang, Y. Hong, Z. Gu, L. Cheng, Z. Li, C. Li, Molecular structure and digestibility of banana flour and starch, Food Hydrocoll. 72 (2017) 219-227.

[42] L. Copeland, J. Blazek, H. Slaman, M.C. Tang, Form and functionality of starch, Food Hydrocoll. 23 (2009) 1527-1534.

[43] M.Z. Sitohy, S.S. El-Saadany, S.M. Labib, M.F. Ramadan, Physicochemical properties of different types of starch phosphate monoesters, Starch/Stärke 52 (4) (2000) 101-105.

[44] N. Charoenkul, D. Uttapap, W. Pathipanawat, Y. Takeda, Physicochemical characteristics of starches and flours from cassava varieties having different cooked root textures, LWT Food Sci. Technol. 44 (8) (2011) 1774-1781.

[45] D.P.R. Ascheri, L.D. Pereira, S.M.C. Bastos, Chemical, morphological, rheological and thermal properties of Solanum lycocarpum phosphorylated starches, Revista Ceres 61 (4) (2014) 458-466. 